\title{
Sounds of Home: A Survey of Local Music Collection Management Practices in Canadian Libraries
}

\author{
by Carolyn Doi and Sean Luyk
}

\section{Abstract}

This paper describes the findings of a national survey of local music collection managers in Canadian libraries in 2018. The survey aims to capture a snapshot of local music collection management practices by identifying areas where collection managers make use of specialized skills and competencies and where practices may be improved. An online questionnaire was sent to local music collection managers in Canadian libraries and consisted of 20 questions that addressed demographics, collection scope, collection development, promotion, access, and preservation.

The results show that local music collections are diverse in scope and include a wide range of formats. Many include archival materials or are described or organized using archival principles. Collection managers use a range of strategies to build and develop local music collections, including working with community members and donors to identify, select, and purchase collection materials. Collections are used most frequently by community members and researchers to conduct scholarly or historical research. Outreach and promotion are areas where collection managers are using diverse strategies, including community engagement, event hosting, and online marketing, to build awareness of collections. Physical and digital preservation practices are being implemented by most participants, and online access to collections is often available through additional collection description or digitization.

Collection managers may face challenges due to the unique nature of local music collections. Strategies for collection management, collection development, outreach, or promotion may fall outside traditional professional skill sets or competencies. Areas for development include donor relations, community engagement, and archival collection management.

Carolyn Doi (carolyn.doi@usask.ca) is the Music \& Education Liaison Librarian at the University Library, University of Saskatchewan. Sean Luyk (sean.luyk@ualberta.ca) is Discovery \& Web Services Librarian at the University of Alberta Libraries.

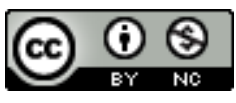

This work is licensed under a Creative Commons Attribution-NonCommercial 4.0 International License. 


\section{Introduction}

The idea of the "connectedness of music" - to specific places and spaces-is a compelling one. Many forms of cultural production, such as books, films, television, and news media, have capitalized on the associations between musical genres and geographic locations. Although these associations do not accurately depict the multitude of local musical cultures active in a location at a given time and fail to represent the realities of how musical cultures operate within the shifting boundaries between the local, national, and global, the association they make between music and place is powerful. Local music, and by extension local music collections, are rich sources of information that can inform bigger questions that build on this idea of connection and the interplay between the local, national, and global in music. Those who develop and maintain local music collections in cultural heritage institutions have a similarly important part to play in answering these questions. By examining their collection management practices, we can begin to better understand the nature of local music materials, the role that local music collections play in preserving historical narratives, and the interplay between the local music community (musicians, fans, collection users, donors, etc.) and the institution.

This paper describes the results of a survey of Canadian local music collectors in Canadian libraries administered in May 2018 as part of the SSHRC supported project: Sounds of Home: Exploring Local Music Collections and Collecting Practices in Canada (hereafter referred to as Sounds of Home). The purpose of the Sounds of Home project is 1 ) to identify where collections of local music are held, what music(s) they document, and what evidentiary value they possess; and 2) to understand the perceived value of collecting local music, and to record local music collection management practices currently used by public institutions to determine areas where practices may be improved. The survey described in this paper represents the first phase of Sounds of Home, the purpose of which was to increase our understanding of the locations of local music collections in Canadian libraries, to document the practical strategies collectors use, and to document the challenges they face with regard to this work. Within Sounds of Home more broadly, music collections are defined as "local" when they demonstrate a connection - through a person, organization, or topic - to a delimited geographic region. The survey data informs us of the current professional practices of local music collectors, provides some possible areas for improving collecting practices, and suggests ideas for future research on the topic of local music collecting. The research addresses a significant gap in the professional and scholarly literature on the topic of local music collecting in libraries and, for the first time, reports on the impressions and practices of local music collection managers in libraries in an aggregate format.

\section{Background}

One of the major motivating factors for this research is the theory that local music collections form the basis of broader understandings of music and its relationship to national and global identities. The work and perspectives of local music collection managers play an essential role in understanding this relationship. This is especially important in the Canadian context because 
Canadian music is already an underrepresented area of study, and Canadian local music is arguably even more so. In his examination of the history of music in Edmonton, Alberta, Gramit notes that studies of local music have historically been situated at the margins of musicological research, and within the field of American music studies, the few studies on local music cultures that do appear tend to be about major metropolitan areas. ${ }^{1}$ Having the source materials available to study local music histories that are at the margins is, therefore, one important act in addressing this gap. Enhanced understandings of the role of local music collections as contributors to identity will be of great value across a wide range of cultural, media, and historical studies.

Frameworks supporting this research include music studies, and library and archival sciences perspectives. With regard to the musicological perspective, this work is grounded in the "scenes approach," which argues that local music scenes are part of broader cultural formations that may act as texts in the construction of evolving and contested identities. In this approach, local music is considered as both locally significant and also connected to the wider world. As Bennett writes, local music illustrates "the importance of locality, and local structures of feeling, in revealing the significance of musical life - and the connectedness of music to other aspects of local history, heritage and culture." 2

Straw is credited with first introducing the scenes approach through a scholarly lens, diverging from previous work that drew upon discussions of genre based on typically commercial constructs. ${ }^{3}$ Scholarship on music scenes has since focused primarily on independent popular music scenes that operate outside of conventional means of distribution. This scholarship has employed wide-ranging methodologies, including cultural studies, the sociology of music, and popular music studies. ${ }^{4}$ The concept of the music scene provides us with a useful theoretical framework to draw upon when considering the practice of local music collecting, given the importance it places on ideas of space and place as they inform understandings of cultural production, including music. Related research in

1. David Gramit, "The Transnational History of Settler Colonialism and the Music of the Urban West: Resituating a Local Music History," American Music 32, no. 3 (2014): 272-73, https://doi.org/10.5406/americanmusic.32.3.0272.

2. Andy Bennett, "Popular Music and the 'Problem' of Heritage," in Sites of Popular Music Heritage: Memories, Histories, Places, Routledge Studies in Popular Music 4 (New York: Routledge, 2015), 24.

3. Will Straw, "Systems of Articulation, Logics of Change: Communities and Scenes in Popular Music," Cultural Studies 5, no. 3 (1991): 368-88.

4. Core research on music scenes includes: Richard A. Peterson and Andy Bennett, Music Scenes : Local, Translocal \& Virtual (Nashville, TN: Vanderbilt University Press, 2004); Andy Bennett, "Consolidating the Music Scenes Perspective," Poetics: Journal of Empirical Research on Culture, the Media and the Arts 32, no. 3-4 (2004): 223-34; Holly Kruse, Site and Sound: Understanding Independent Music Scenes, Music/Meanings, vol. 1 (New York, NY: P. Lang, 2003); John Connell and Chris Gibson, Sound Tracks : Popular Music, Identity, and Place, Critical Geographies 17 (London: Routledge, 2003). 
ethnomusicology, that has also sought to unpack definitions of local music and its relationships to national or global musics, is further instructive in this research. ${ }^{5}$

When considering local music collecting and the library, we draw on the disciplines of special collections librarianship and particularly local heritage collecting. As Dixon writes, "local studies collections are almost as old as libraries themselves." ${ }^{16}$ Preservation, stewardship, access, and management of historical collections and original artifacts serve as cornerstones of the professional knowledge in this discipline. ${ }^{7}$ Dewe, writing about the value of local history materials in libraries, argues that these collections make a contribution "...toward an understanding and interpretation of regional and national history... [and] as having social values for individuals and groups... [this] shared sense of local history, and an involvement with it, can also be seen as a way of strengthening communities and helping move towards the goal of social inclusion." 8 While the benefit of local heritage collections in libraries is clear, Dewe goes on to advocate for better training and subject knowledge for library staff who serve the local community and build local collections to "meet the needs of demanding users who look for a depth of subject knowledge."

There are parallels between the challenges and professional needs of local heritage collecting and local music collecting. Berger's work in this area is especially relevant as he discusses practical questions of how local music collections may best be preserved and presented. ${ }^{9}$ Early in the history of music librarianship as a profession, Spivacke argued that local music collecting impacts both local communities and the nation by providing more "complete" musical histories. ${ }^{10}$ Epstein made similar arguments, suggesting that through the activity of collecting and compiling local music collections, libraries can help connect local musical pasts to national cultural and social developments. ${ }^{11}$ She would prove these claims to be true nearly a decade later, through her significant contributions to the study of African-American musical culture, drawing extensively on the use of local music

5. Significant ethnomusicological works include: Jocelyne Guilbault, "On Redefining the Local through World Music," in Ethnomusicology: A Contemporary Reader (New York: Routledge, 2006), 137-46; Jan Fairley, "The 'Local' and 'Global' in Popular Music," Cambridge Companions to Music (New York, NY: Cambridge University Press, 2001), 272-89; Ian D. Biddle and Vanessa Knights, Music, National Identity and the Politics of Location : Between the Global and the Local, Ashgate Popular and Folk Music Series (Burlington, VT: Ashgate, 2007).

6. Diana Dixon, "From Manuscripts to Metadata: The Changing Face of Local Studies Librarianship," APLIS 24, no. 2 (June 2011): 74.

7. American Library Association, "Guidelines: Competencies for Special Collections Professionals," July 8, 2008, http://www.ala.org/acrl/standards/comp4specollect.

8. Michael Dewe, "Local Studies and Libraries," in Local Studies Collection Management (London: Routledge, 2016), 4.

9. Sidney E. Berger, "What Is So Rare...: Issues in Rare Book Librarianship," Library Trends 36, no. 1 (1987), http://hdl.handle.net/2142/7513.

10. Harold Spivacke, "Collection of Musical Material of Local Interest," Music Library Association Notes, no. 8 (August 3, 1940): 49-54.

11. Dena J. Epstein, “On Collecting Materials for Local Music Histories," Notes: Quarterly Journal of the Music Library Association 24, no. 1 (1967): 18-21, https://doi.org/10.2307/894777. 
sources. ${ }^{12}$ More recent publications in music librarianship on local music collections include case studies that describe individual collections; ${ }^{13}$ articles that advocate for the importance of collecting local music; ${ }^{14}$ discussions of practical challenges related to the collection, storage, and accessibility of local music artifacts; ${ }^{15}$ and examinations of local music collections in the media. ${ }^{16}$ More broadly, a growing body of literature about cultural heritage institutions and local music also informs this research, including literature on local music in museums and archives, the evolving role of community archives, ${ }^{17}$ and work concerning the role of amateurs in collecting and documenting popular music material culture. ${ }^{18}$

\section{Method}

Both the professional and theoretical background presented here informed the survey design and research questions. When constructing the survey, we followed Bhattacherjee's methodology for online questionnaire surveys. ${ }^{19}$ The online questionnaire was created in English (see Appendix 1:

12. Dena Epstein, Sinful Tunes and Spirituals: Black Folk Music to the Civil War (Urbana: University of Illinois Press, 2003).

13. Robert Murrell Stevenson, "Local Music History Research in Los Angeles Area Libraries," Inter-American Music Review 10, no. 1 (1988): 19-38; Edward W. Hathaway, "Developing a State Archive of Local Music Materials," Notes: Quarterly Journal of the Music Library Association 45, no. 3 (1989): 483-94; Lara Allen, "Preserving a Nation's Heritage: The Gallo Music Archive and South African Popular Music," Fontes Artis Musicae, no. 3 (2007): 263; Jeff Wanser, "Collecting and Collaborating to Build Community: The Evolution of a Local Music Collection at a Small Liberal Arts College Library," Technical Services Quarterly 31, no. 4 (October 2, 2014): 332-57, https://doi.org/10.1080/07317131.2014.908586; Priscilla Winling, "Bringing the Local Music Scene to the Public Libraries Network of Strasbourg: A Live Collection," Fontes Artis Musicae 59, no. 2 (2012): 127-33, http://www.jstor.org/stable/42765570.

14. Sean Luyk, "Scene but Not Heard: Collecting Local Music," CAML Review / Revue de l'ACBM 41, no. 1 (2013): 22-33; John Vallier, "Sound Archiving Close to Home: Why Community Partnerships Matter," Notes: Quarterly Journal of the Music Library Association 67, no. 1 (2010): 39-49.

15. Michael Rafferty, "Compiling a Comprehensive Local Music Archive - Some Problems," Local Studies Librarian 20, no. 2 (2001): 12-13; Richard Belford, "Building a Regional Music Collection: The Saskatchewan Experience," CAML Review / Revue de l'ACBM 35, no. 1 (2007): 19-22; Carolyn Doi, "Local Music Collections in Cultural Heritage Institutions: A Qualitative Systematic Review," Fontes Artis Musicae 65, no. 4 (2018); Carolyn Doi, "Local Music Collections: Strategies for Digital Access, Presentation, and Preservation-A Case Study," New Review of Academic Librarianship 21, no. 2 (2015): 256-63, https://doi.org/10.1080/13614533.2015.1022663.

16. Veronica Kmiech, "In Other News: The Significance of Canadian Media Sources in an Analysis of Local Music Collection Literature," CAML Review / Revue de l'ACBM 46, no. 1 (2018): 6-16.

17. Sarah Baker and Jez Collins, "Sustaining Popular Music's Material Culture in Community Archives and Museums," International Journal of Heritage Studies 21, no. 10 (2015): 983-96, https://doi.org/10.1080/13527258.2015.1041414; Sarah Baker, Peter Doyle, and Shane Homan, "Historical Records, National Constructions: The Contemporary Popular Music Archive," in Popular Music and Society, vol. 39 (Abingdon, Oxfordshire, United Kingdom: Routledge, 2016), 8-27; Marion Leonard, “Constructing Histories through Material Culture: Popular Music, Museums and Collecting," Popular Music History 2, no. 2 (2007): 147-67, https://doi.org/10.1558/pomh.v2i2.147.

18. Sarah Baker, ed., Preserving Popular Music Heritage: Do-lt-Yourself, Do-It-Together, Routledge Research in Music 11 (New York: Routledge, 2015).

19. Anol Bhattacherjee, Social Science Research: Principles, Methods, and Practices, Textbooks Collection 3 (Global Text Project, 2012), https://scholarcommons.usf.edu/oa textbooks/3/. 
Questionnaire, English) and translated to French (see Appendix 2: Questionnaire, French). The study received an ethics exemption from the University of Saskatchewan on November 8, 2017, and ethics approval at the University of Alberta on November 29, 2017. The survey was coded using Voxco survey software and administered by the Social Sciences Research Lab at the University of Saskatchewan. A link to the survey and invitation to participate were distributed by email to potential participants on May 3, 2018. Two reminders were sent prior to the survey closing on May 22, 2018. Local music collectors working in Canadian libraries were invited to participate. These included public library contacts in major Canadian cities, music librarians and special collections librarians from academic institutions, music conservatory librarians, and music librarians at national libraries and music research centres. Additional potential participants were identified by sending the survey to public libraries in major cities, academic music libraries, and other likely institutions. We made our selection from directories for professional associations and organizations (e.g., Canadian National Digital Heritage Index, Canadian Association of Music Libraries) and publicly available online information from provincial post-secondary institution directories. Potential survey participants were required to answer a qualifying question that asked if they managed a local music collection where the scope was a delimited geographic area (e.g. town, city, neighborhood, province, territory, region, etc.) in order to be included in the study.

The survey consisted of 20 questions: 16 closed questions (yes/no, multiple choice, and ranking), and four open-ended. Questions were divided into six categories: demographics, collection scope, collection development, promotion, access, and preservation. The survey preamble provided a definition of local music collections and participants were excluded from the survey if they did not identify as a manager of a local music collection at a Canadian library.

\section{Results}

Of the 105 potential participants identified, 49 (46.66\%) opened the survey link in the recruitment email. Twenty-four participants did not complete the survey and 12 did not meet eligibility screening and were excluded from the survey. Thirteen participants completed the survey and were included in this study. ${ }^{20}$ The majority $(8,61.5 \%)$ of the participants are located in Western Canada, followed by three (23.1\%) from Central Canada, and two (15.4\%) from Eastern Canada. The majority of participants work at academic institutions $(8,61.5 \%)$, followed by public libraries $(3,23.1 \%)$ and special libraries $(2,15.4 \%)$. See table 1 for a more detailed breakdown of geographic and institutional representation.

20. Carolyn Doi and Sean Luyk, “Local Music Collections and Collecting in Canada," September 18, 2018, https://doi.org/10.7939/DVN/WAJ9UG. 
Table 1: Participants

\begin{tabular}{|c|c|c|c|c|c|c|}
\hline Region & Province & Academic & Public & Special & $\begin{array}{l}\text { Frequency } \\
\text { total }\end{array}$ & Percentage \\
\hline \multirow[t]{4}{*}{$\begin{array}{l}\text { Western } \\
\text { Canada }\end{array}$} & $\begin{array}{l}\text { British } \\
\text { Columbia }\end{array}$ & 2 & 0 & 0 & 2 & $15.38 \%$ \\
\hline & Alberta & 1 & 1 & 1 & 3 & $23.08 \%$ \\
\hline & Saskatchewan & 1 & 0 & 0 & 1 & $7.69 \%$ \\
\hline & Manitoba & 1 & 0 & 1 & 2 & $15.38 \%$ \\
\hline Central Canada & Ontario & 1 & 2 & 0 & 3 & $23.08 \%$ \\
\hline \multirow[t]{2}{*}{ Eastern Canada } & Newfoundland & 2 & 0 & 0 & 2 & $15.38 \%$ \\
\hline & Total & 8 & 3 & 2 & 13 & $100.00 \%$ \\
\hline
\end{tabular}

\section{Collection descriptions}

We asked participants to describe their local music collections, including growth, scope, and formats. Almost all participants $(12,92.31 \%)$ indicated that their collections are currently growing (Q11). When describing the scope of their collections, participants used a variety of definitions of "local music" to limit the scope. In some cases, the scope statements described limitations based on the institution, city, or province:

"[The collection is] mostly focused on music created and performed at [the institution]."

"Our database ... aims to identify all NL recordings, even those we don't own."

"The 'local music' collection at the [Institution] mainly focuses on Manitoba composers, faculty performers, and publications of graduates and faculty of our program."

Participants also attempted to define the collection by additional limits. It was quite common to see references to format and material types that may be included:

"We collect: commercial recordings by Newfoundlanders and Labradorians (resident or nonresident) and commercial recordings produced in Newfoundland and Labrador (including those by non-Newfoundlanders); commercial DVDs of musical performances; monographs concerning NL music; song-books and guides to teaching instruments."

"...mostly collections housed in archives and special collections." 
"Our scope is to obtain popular local music on CD and through our streaming platforms Freegal and Hoopla."

Scope statements also made references to the types of artists or music included in the collection, or the types of topical content that are collected:

"To collect music recorded in Saskatchewan, sheet music by Saskatchewan composers and both recorded and music composed by musicians (including singers, songwriters, bands, indigenous groups and classical musicians - either originally from Saskatchewan or living there now)"

"We have Biography files containing newspaper clippings about musicians/performers. We also have a database (Periodical Article Bibliography) that would help identify magazine and journal articles about NL music."

Participants were asked to indicate which formats were included in the local music collections (fig. 1). All participants (100\%) indicated that sound recordings are included, followed by video recordings (69.23\%), notated music (61.54\%), and concert programs (61.54\%). Participants who selected the response "other" included formats such as "personal and professional correspondence, and other textual records included in archival fonds" and "archival records" in their responses.

\section{Figure 1: Collection formats}

Q5 What formats are included in the local music collections?

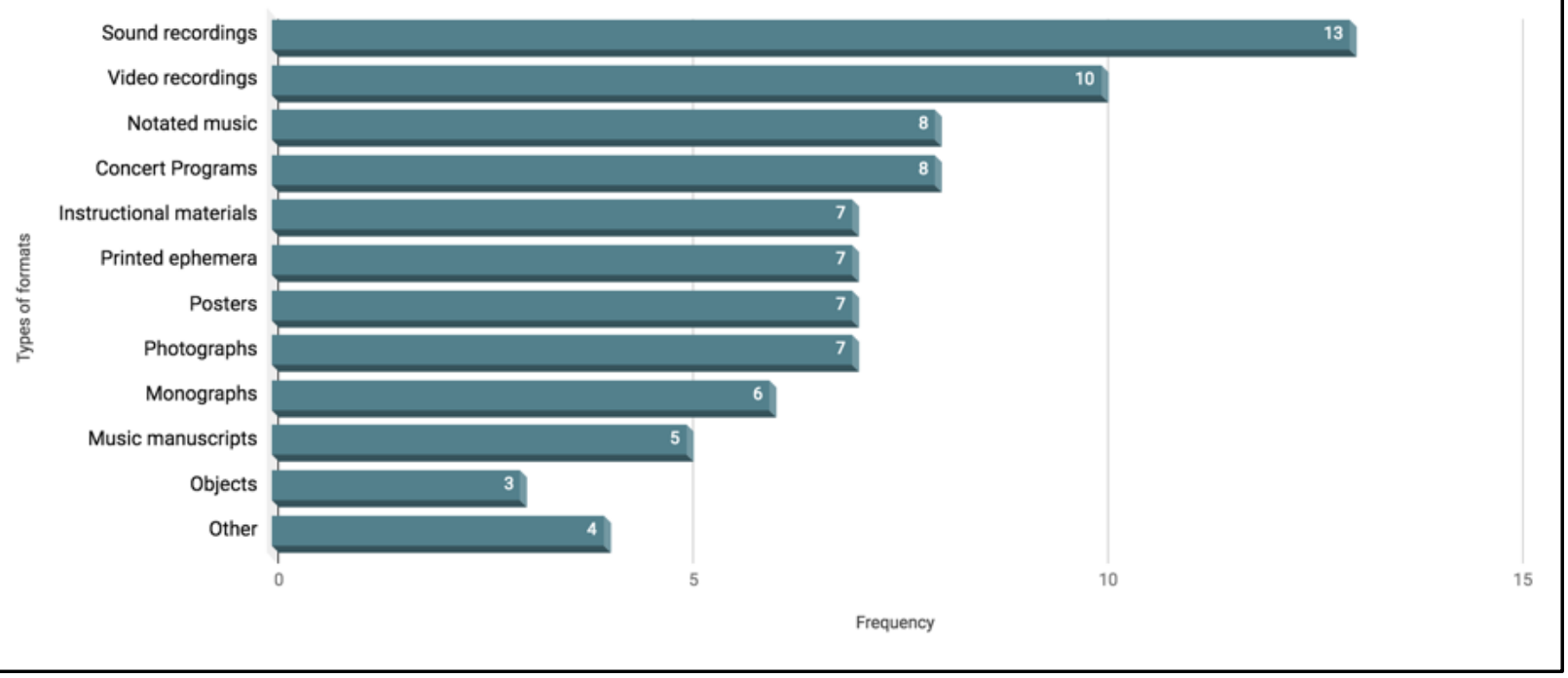




\section{Access and preservation}

We asked participants where and how they provide access to the local music collections and how they are preserved. When asked how users are currently able to access the collections (Q6), all participants (100\%) responded that collections are accessible in person. Of those, eight (61.53\%) responded that the collections are also available online. Two participants clarified their responses in the open-ended portion of the question to indicate that their collections came with limitations on access. One participant indicated, "much of our backlog material is only accessible with the donor's written permission." Another participant said: "Vimeo [is used] for some recordings [but this is] very limited."

In response to the question asking where local music collection materials are located, most participants $(8,61.54 \%)$ indicated that materials are located in an archive or special collections unit (fig. 2). Other locations included interfiling with other music collections $(6,46.15 \%)$, storage (5, $38.46 \%)$, a special collection within a music library $(4,30.77 \%)$, and within another local history collection ("other," 1, 7.69\%). Participants were able to select more than one location where collection materials were held, which accounts for the greater number of responses than the total number of participants.

\section{Figure 2: Physical location of local music collections}

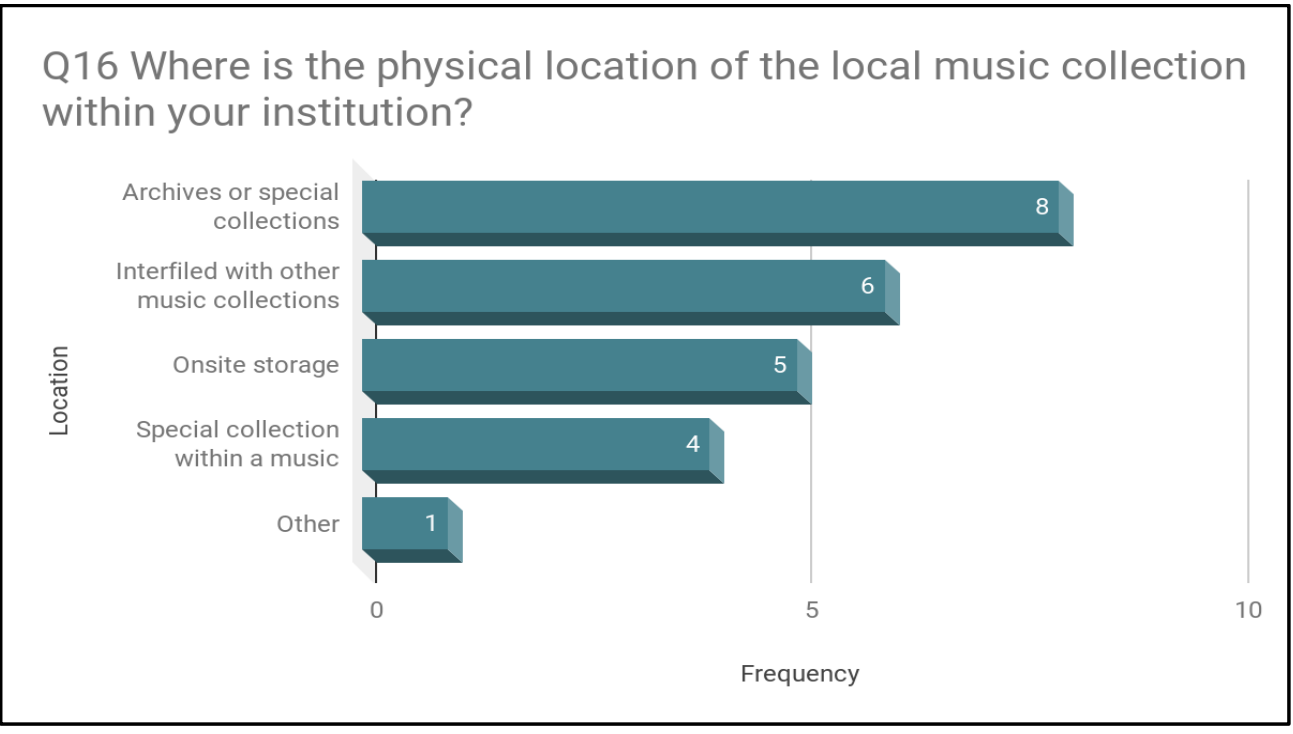

When asked if the local music collections have been catalogued, participants responded that cataloguing of some kind has been done. Nine participants $(69.23 \%)$ responded that the collection had been fully catalogued while four (30.77\%) responded that the collection has been partially catalogued. Based on these responses, we asked participants whether they have used any metadata in catalogue records to indicate that collection materials are part of a local music collection. In response, the majority $(9,69.23 \%)$ answered that metadata has been applied, while a few answered that additional metadata has not been applied $(3,23.08 \%)$, and one participant indicated 
that it is sometimes applied (7.69\%). If participants indicated that metadata is applied (with all or some materials), then they were asked how metadata is used to indicate that materials are part of a local music collection. Of the 10 participants who indicated that metadata is used to identify items held in a local music collection, four use an added series note or added subject headings. Four participants selected the "other" option, which included metadata strategies such as adding a local note, ISAD(G) metadata, ${ }^{21}$ archival description, and using a separate collection location.

Table 2: Use of metadata to indicate inclusion in a local music collection

\begin{tabular}{|l|lll|}
\hline \multicolumn{2}{|c}{ Frequency } & Percentage & Cumulative percentage \\
\hline Added series note & 4 & $28.57 \%$ & $28.57 \%$ \\
Added subject headings & 4 & $28.57 \%$ & $57.14 \%$ \\
Added name field & 2 & $14.29 \%$ & $71.43 \%$ \\
Other & 4 & $28.57 \%$ & $100.00 \%$ \\
Total & 14 & $100.00 \%$ & \\
\hline
\end{tabular}

When asked what steps have been taken to preserve the collection materials (Q17), the majority of participants reported that they are implementing digital preservation strategies $(9,47.37 \%)$, while others noted that they are implementing physical preservation strategies $(6,31.58 \%)$. Participants were able to select both digital and physical preservation as options in this question. When asked to respond to the question "what steps have been taken to physically preserve collection materials" (Q18), participants responded with a variety of strategies. Several mentioned the use of archival preservation practices:

"...archival arrangement and description, environmental controls in storage facility, enforcing proper handling techniques in the reference room."

"...acid-free file folders in acid-free boxes."

In regard to the supervised access and use of local music collection materials, responses included:

"[materials] must be used within the library. They don't leave the library. Quality playback equipment has been provided to limit wear and tear on original materials. Specialized (custom) media storage/browsing cabinets have been constructed."

21. The General International Standard Archival Description (ISAD(G)) is used to "identify and explain the context and content of archival material in order to promote its accessibility." International Council on Archives, https://www.ica.org/sites/default/files/CBPS 2000 Guidelines ISAD\%28G\%29 Second-edition EN.pdf. 
"Advocacy for a specialized vault. Our on-site Preservation Officer provides services for damaged, or at-risk items."

When asked to respond to the question "what steps have been taken to digitally preserve collection materials" (Q19), participants responded primarily with examples of digitization as a means of preserving collection materials. Several participants emphasized the need to digitize materials that are in unstable formats:

"Digitizing in preservation formats that have backwards and forwards compatibility; triaging so that the most unstable formats are digitized and preserved first"

"Obsolete media have been migrated to digital formats."

"Digitization of at-risk media is ongoing. DVDs are backed up into various formats that are stored on a secure server. The Library is currently testing digital management programs for the long-term preservation and access."

Other participants mentioned digitization of specific formats or specific projects:

"Digitization of audio recordings"

"Beginning to digitize and create an online database of recital works."

"There is also an on-going program that is digitizing the collection or at least part of the collection, which will then become digital assets that will become part of the digital preservation strategy."

\section{Use of local music collections}

We asked participants to identify the users of their local music collections and to describe the ways the collections are used. In Q8, participants were asked to identify the users who access the local music collections and to rank these users by the frequency of use. The most frequent users are community members who were identified as users in 11 cases, and of these, eight $(72.72 \%)$ were identified as primary or secondary users of the collection. Researchers were also identified as frequent users of local music collections in 11 cases, and of these, seven (63.63\%) are identified as primary or secondary users. Other user groups that used the collections less frequently included students, visitors from other communities, and donors (fig. 3). 
Figure 3: Users of local music collections

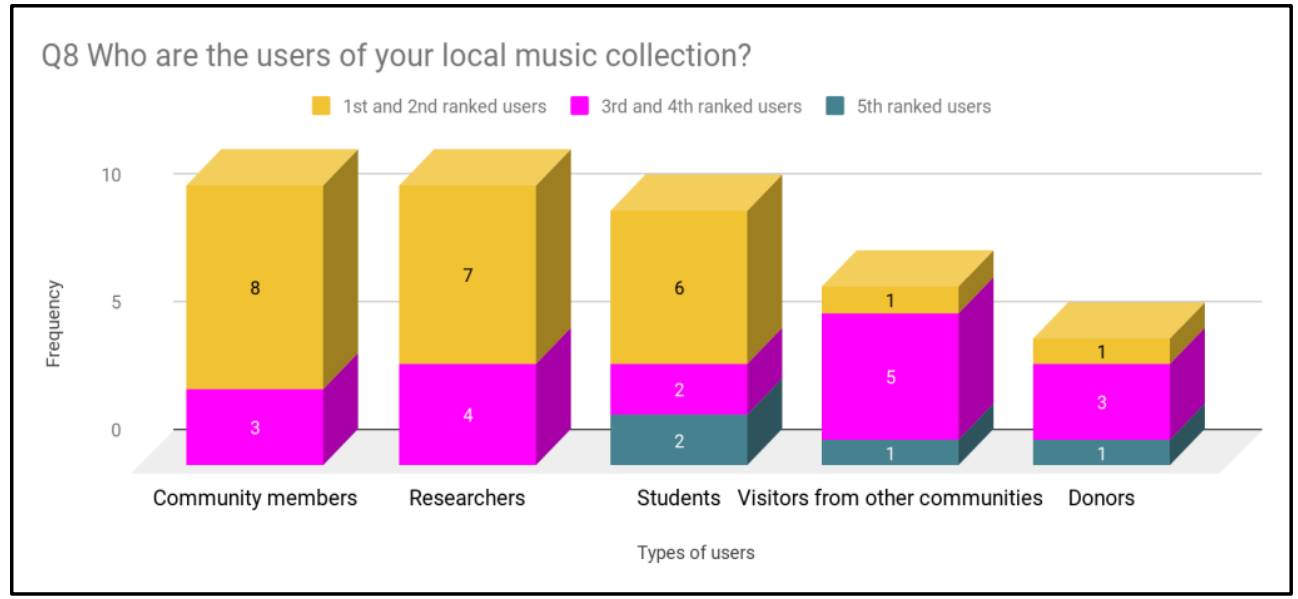

In response to the question "how do users make use of your local music collections?" (Q9) the highest ranked uses are scholarly research (7, 53.85\%) and historical research (6, 46.15\%). Subsequent uses include teaching, community research, artistic work, and family research. One participant indicated that they do not know how the collection is used (fig. 4). Open-ended responses for this question indicate more specific examples of collection use:

"[to] learn about local artists, entertainment"

"for use in musical performance or study"

"[in] creative projects: remounts of shows, re-staging of shows/pieces, creation of new creative works (plays, dance, music)"

"Heritage Fairs at schools"

"[to allow] music collectors [to] check their lists against our holdings"

\section{Figure 4: How local music collections are used}

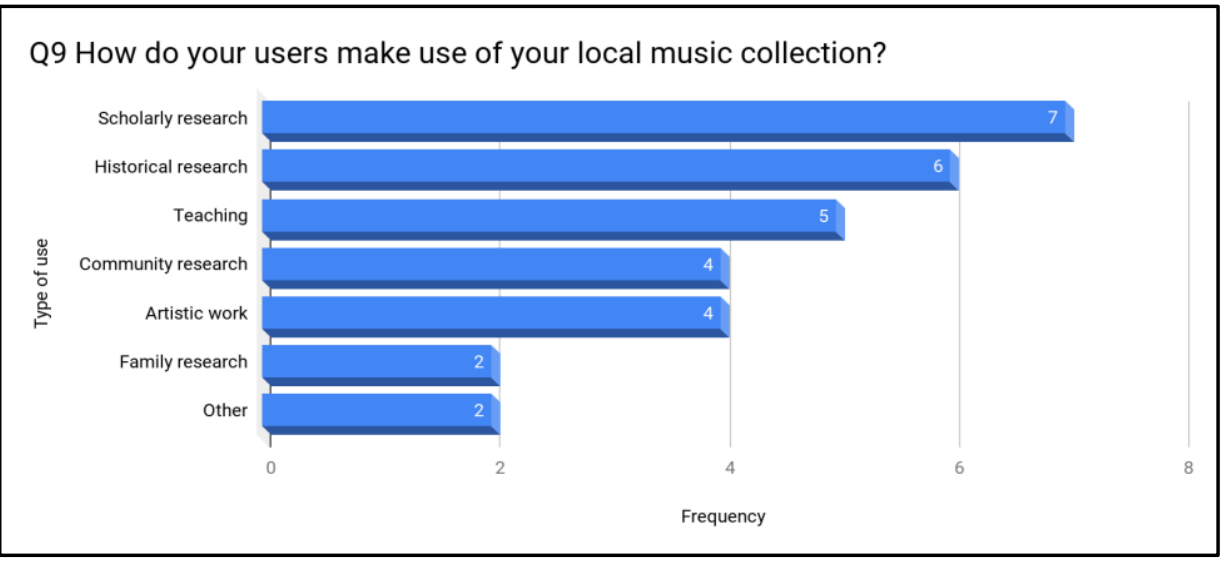




\section{Acquisitions}

We asked the participants about the acquisitions process, including where and how they identify, select, and obtain materials for the collections (Q11, Q13, and Q15). When asked to rank the usefulness of tools or strategies for identifying and selecting collection materials, most participants identified conducting research on local music as either useful or very useful (11, 84.61\%). Gathering collecting suggestions through community engagement events and establishing or updating a collection development policy were also identified as useful or very useful strategies $(7,53.84 \%)$. Other options are also used but considered less useful, such as building community partnerships, selecting from offerings at music stores/vendors, building lists, and getting suggestions through media sources (fig. 5).

Figure 5: Tools and strategies for identifying and selecting collection materials

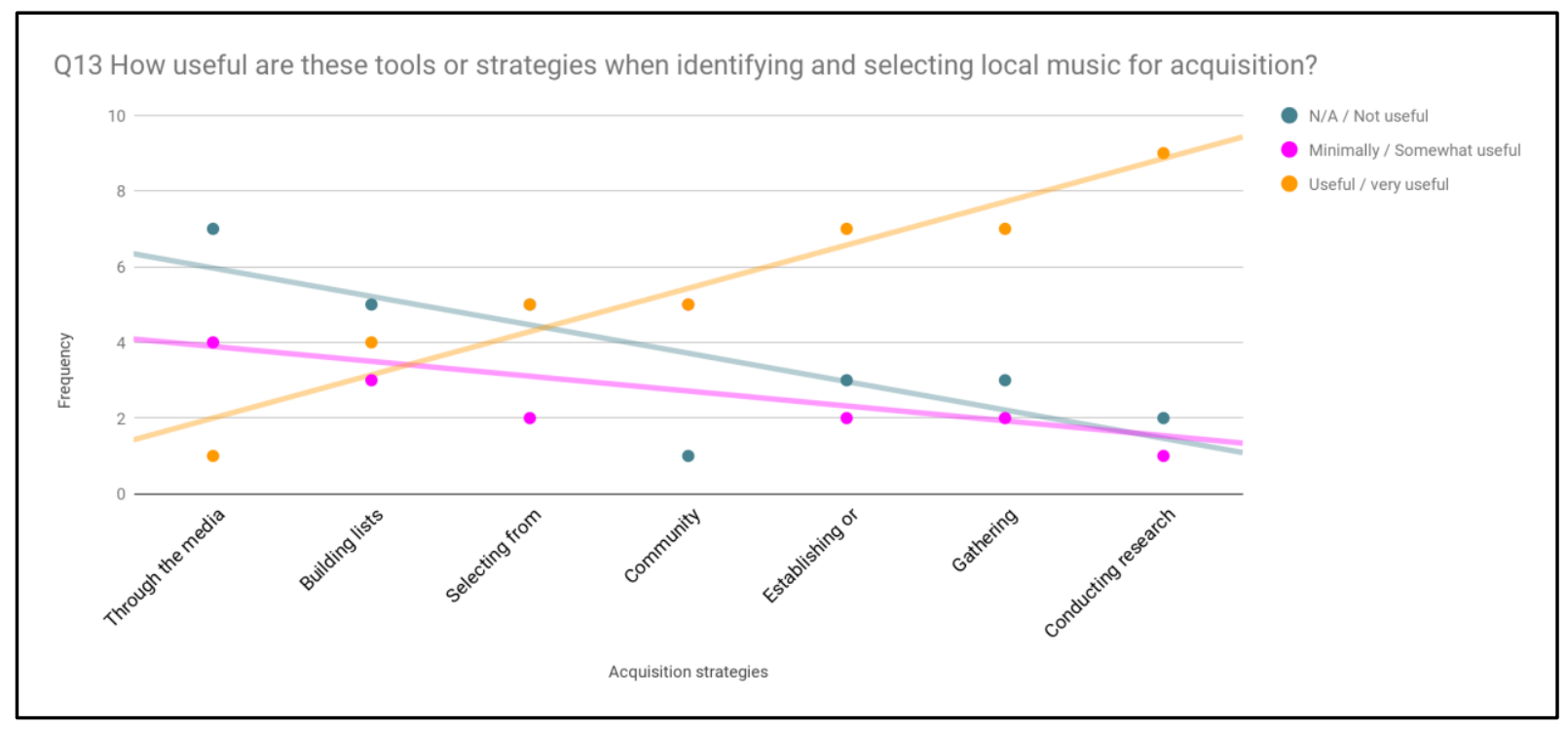

When asked how often certain sources were used when acquiring local music materials, "music stores and vendors" was identified by the most participants as a source they used frequently or very frequently $(6,46.15 \%)$. This was followed closely by acquiring materials through donations and from individual artists and bands (5,38.46\%). Other methods included acquisitions by way of community organizations, music labels and publishers, self-produced sound recordings, purchases at events, and through social media (fig. 6). 
Figure 6: Local music acquisition sources

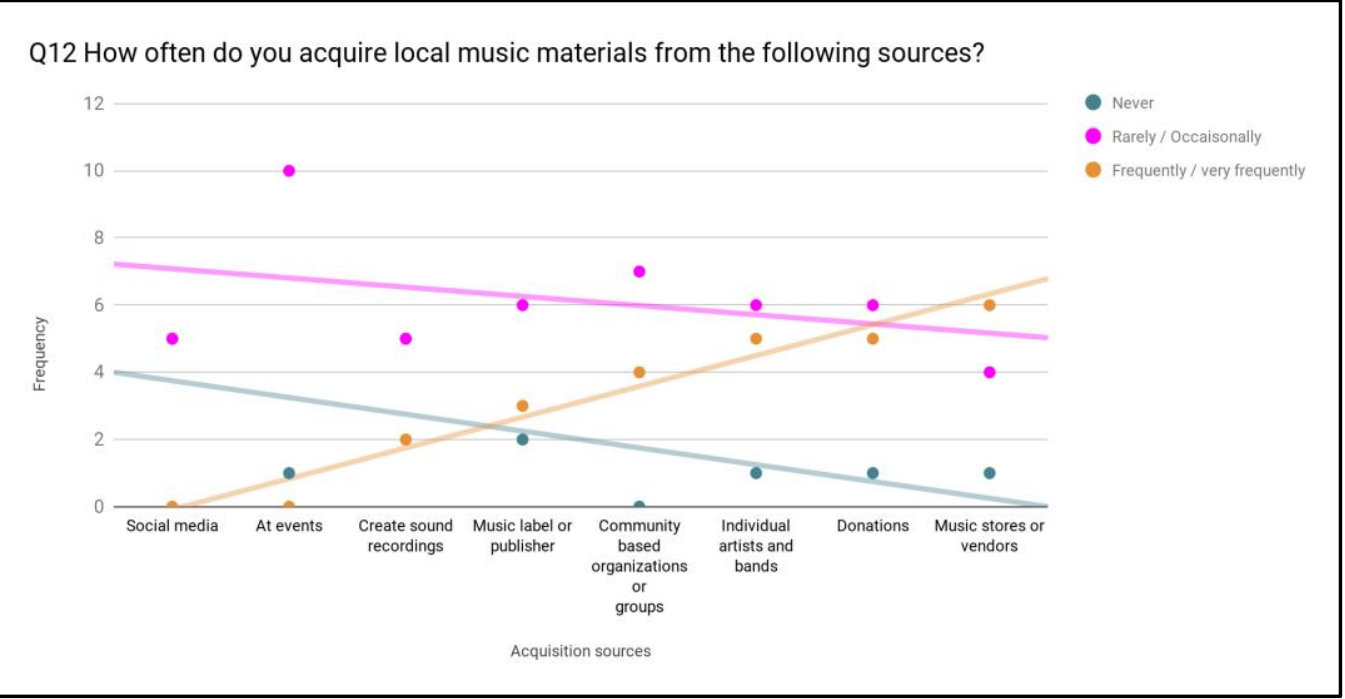

Participants were asked to identify and rank acquisition strategies for collecting local music materials. Establishing donor agreements and licensing agreements were ranked as the most important strategies. Of those who selected donor agreements as an acquisition strategy (10, $76.92 \%)$, three participants identified this as their primary or secondary strategy. Of those who selected licensing agreements as an acquisition strategy, five identified this as either a primary or secondary strategy. Other strategies include maintaining flexibility, advocacy, hosting events to collect local music materials, and implementing a promotional activity or strategy (fig. 7). One participant selected the "other" option, and included a variety of strategies in their response:

"working with our vendor to help us with our awareness of local works; Speaking with musicians and those who work in recording studios and keeping up-to-date with what's happening on [websites] and reading Arts \& Entertainment guides..."

Figure 7: Strategies for acquiring local music materials

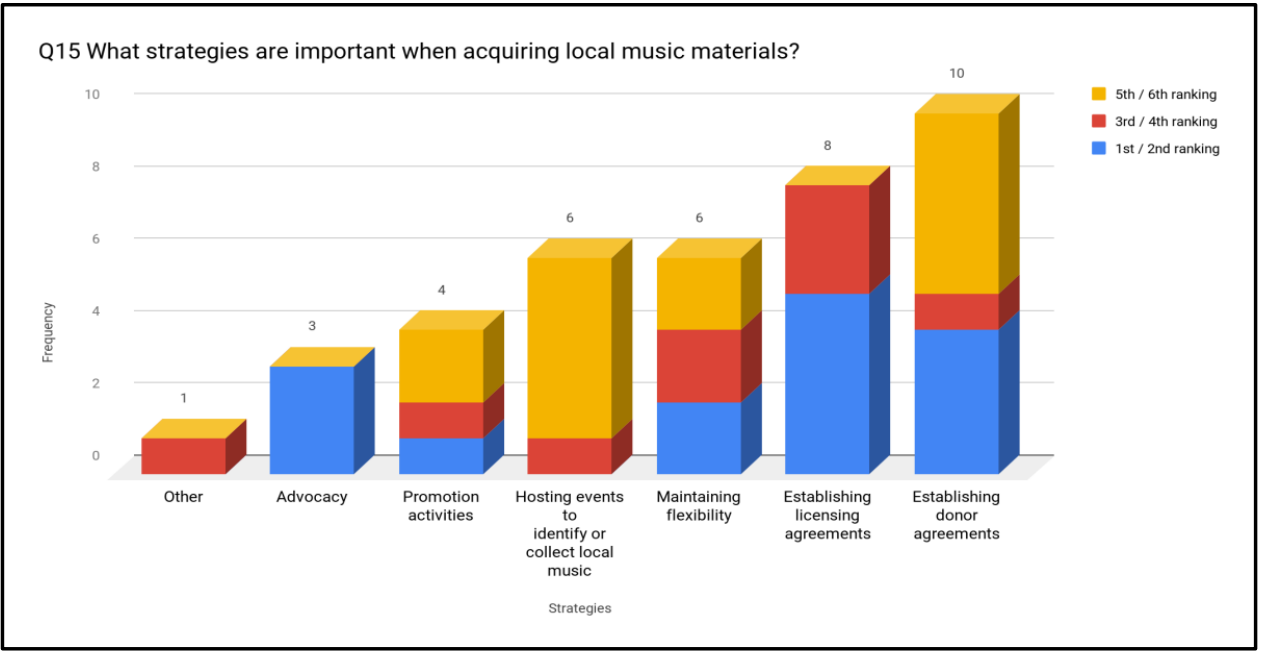




\section{Promotion, outreach, and funding}

We asked participants about how they manage promotion and outreach for their local music collection. When asked how funds for local music collection materials are secured (Q14), participants indicated that most often, funding comes from an institutional collections fund ( 9 , $33.33 \%)$ or through donations from the wider community $(8,29.63 \%)$. Other funding sources include endowment funds, grants, and government funding (see table 3 ). Many participants selected more than one funding source, suggesting that funding sources are varied and that one source may not be sufficient on its own.

Table 3: Funding sources for local music collections

\begin{tabular}{|l|ll|}
\hline \multicolumn{1}{|l}{} & Frequency & Percentage \\
\hline Main institutional collection fund & 9 & $33.33 \%$ \\
$\begin{array}{l}\text { Donations from members of the } \\
\text { community }\end{array}$ & 8 & $29.63 \%$ \\
Designated endowment funds & 5 & $18.52 \%$ \\
Grants & 3 & $11.11 \%$ \\
Government funding & 2 & $7.41 \%$ \\
Total & $\mathbf{2 7}$ & $100.00 \%$ \\
\hline
\end{tabular}

In response to the question "how are local music collection(s) promoted?" collection managers indicated a wide range of strategies, and many have used more than one promotion strategy. The most popular strategy is community engagement, which is used by $69.23 \%$ of participants. This is followed by promotional events and online advertising or social media $(8,61.54 \%)$. Other strategies include the production of print promotional materials, writing scholarly articles, developing collection-specific branding (e.g. logos, slogans, etc.), producing radio programs or podcasts, advertising through the media, and development of promotional film (see fig. 8). Two participants are not doing any promotional work with the local music collection. There were a number of openended responses to the "other" category, including making sure that finding aids are digitized, materials are indexed by Google, producing "online showcases," hosting "in-library concerts," and posting collection content on SoundCloud. 
Figure 8: Promotion strategies

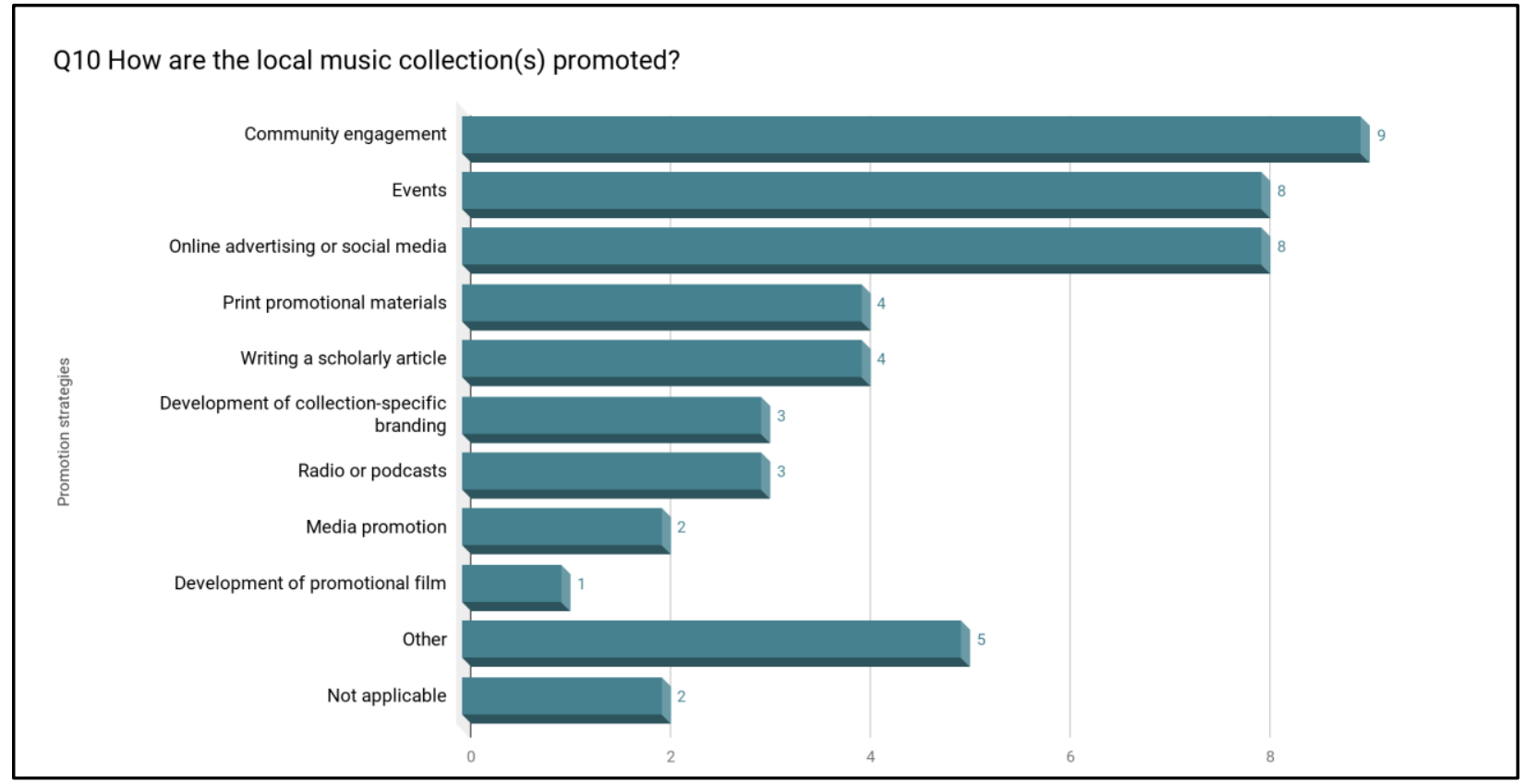

When asked for any additional comments, some participants included details about collecting practices, limitations, and recommendations for practice. Some participants commented on limitations or concerns regarding local music collecting:

"The question of extent will come up, due to eventual storage limitations. Are we trying to collect as comprehensively as possible, or shooting for a representative collection? How often is publicity i.e. a public event/media coverage required to maintain engagement (use and donations)..."

"We do not specialize in collecting local musical archives. It's a big area that costs lots of money and requires expertise that we don't have."

One participant described the role of the library in supporting the local music community beyond collections:

"As a public library our collection is meant to be inclusive of local musicians to help increase their profile. We are also partners in a city-wise [sic] initiative to promote local music."

With regard to the role of community and access, one participant noted:

"Working with the musical community is key to the development of a robust collection. That can be a challenge when the region is so vast, geographically. Hence, digital access is an important aspect of fostering relationships with individuals and communities that are situated great distances from the institution..." 


\section{Key findings}

\section{Defining a scope statement}

Local music collections are diverse and varied in their definitions and limitations, just like the places that they represent. The way collectors choose to word scope statements reflects this. On the one hand, a collection may be limited solely to materials that document the musical activities of a single institution, while another collection may attempt to document all musical activity that took place within a whole province or region.

While each scope statement is particular to its collection, there are elements common to all: place, format, and affiliation (see fig. 9). The place element may indicate a limitation to a geographic area (e.g. province, region, city, or neighbourhood) or a more specific address (e.g. building, venue, or institution). The format element is used to determine which physical or digital formats are included in the collection (e.g. sound recordings, sheet music, concert posters, etc.). The affiliation element describes the nature of the connection between materials and place. These affiliations could include types of people represented (e.g. bands who performed in a particular city or venue, composers who resided in a particular province, etc.), how materials were produced (e.g. CDs distributed by a local music label), and topical content of the materials (e.g. sheet music with references to place names). The place, format, and affiliation elements are sometimes used singularly, and other times in combination to make up scope statements for local music collections.

Practitioners who are developing local music collections at their own institutions may wish to take these elements into consideration when writing collection development policies, considering materials for acquisition, or proposing new local music collections projects.

\section{Figure 9: Elements of local music collection scope statements}

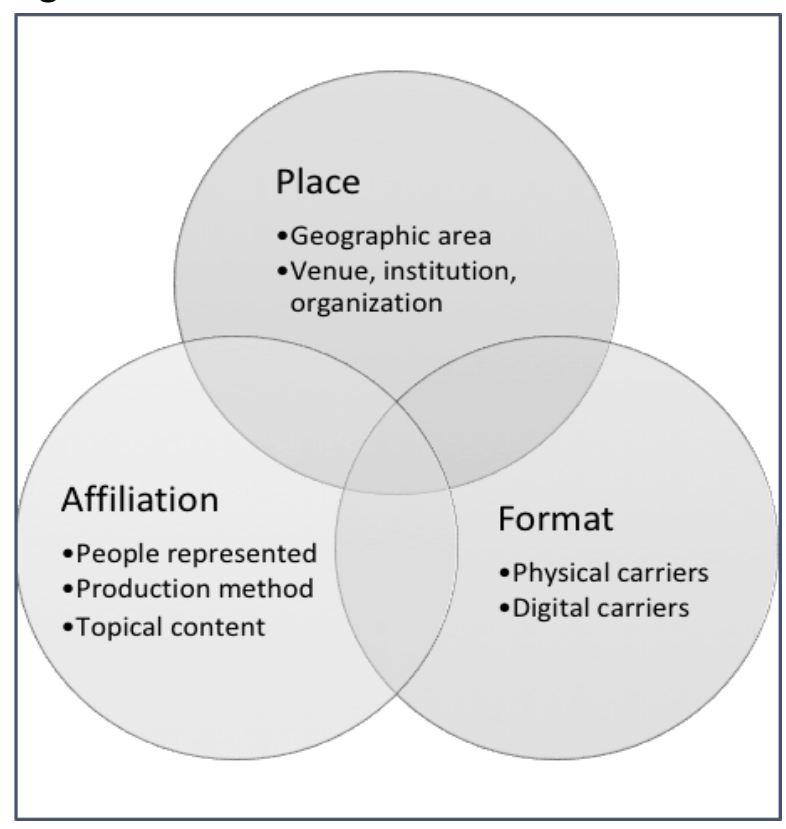




\section{Complexities of practice}

The survey results show that local music collecting is happening across Canada in a variety of library types. The work is complex and multifaceted, due in large part to the range of collection types and musical representations.

While this study is focused on local music collecting in libraries, many of the described collections are actually held alongside archival collections, contain archival materials, or are described using archival standards. This mix of archival and library treatments leads us to conclude that local music collection managers must rely on a wider set of competencies and skills than needed in the development of music collections generally. Most participants are implementing physical and/or digital preservation practices. Similarly, most provide online access to collections.

With regard to collection building, local music collection managers use a wide range of methods for identifying, selecting, and acquiring local music materials. Findings show that work with community members and donors are among the core strategies for building local music collections, although more traditional methods of collection building still remain, such as working with music and library vendors. Relying on community and donors for collection development means that collection managers must establish or build on existing relationships to ensure ongoing support. Outreach and promotion are areas where collection managers are using diverse and creative strategies to build awareness of collections, including community engagement, event hosting, and online marketing.

Practitioners hoping to engage with local music collection work may wish to consider collaborations and partnerships to bring in expertise. Areas of practice where this may be particularly important are donor relations, community engagement or outreach, marketing, digital projects, cataloguing, and archives management.

\section{Community and Relationship-Building}

The concept of 'community' stands out because it impacts all aspects of local music collecting and collections, from descriptions to acquisition processes, use, outreach, and promotion. One of the complexities of the community concept is that it outlines a dual role with regard to local music collecting; the community is both the focus of the collection materials themselves and its creator, in partnership with librarians and other cultural heritage professionals. This dual role presents both challenges and opportunities for collections managers and community members alike. This participant's comment on the topic of providing access illustrates not only the importance of bridging geographic barriers but also the importance of relationship building to ensure collections are used and relevant to community members:

"Working with the musical community is key to the development of a robust collection. That can be a challenge when the region is so vast, geographically. Hence, digital access is an important aspect of fostering relationships with individuals and communities that are situated great distances from the institution." 
The close ties between community and local music collecting invites us to consider how collection managers might choose to engage respectfully with the individuals and communities they work with. ${ }^{22}$ As Kelleher states, "physical and legal custody of records in archives repositories have been central to leveraged and negotiated power among creators, repositories, and users." 23 It is necessary, therefore, for libraries to consider the history of systemic oppression, existing power dynamics, and ongoing injustices that accompany such collecting objectives. We propose a more inclusive approach to community outreach for the purpose of local music collecting. Instead of working with communities for the sole purpose of collecting or documenting their musical history, it is important to consider relationship-building and trust-building as a first step toward further conversation.

The post-custodial model, although applied primarily in archival settings, may serve as a helpful starting place for librarians hoping to work more closely with local music communities, because it "allows communities to maintain ownership of their collections while also receiving institutional support." ${ }^{24}$ The Society of American Archivists defines the post-custodial model as one where "archivists will no longer physically acquire and maintain records, but they will provide management oversight for records that will remain in the custody of the record creators." 25 As Flinn states, this model "addresses the ambivalence that many communities feel towards depositing their archives in formal heritage institutions, but it also avoids the need for professional archivists to make difficult and often upsetting decisions about what is worth depositing and preserving..." ${ }^{26}$ The benefit for libraries who use this model includes closer working relationships, which often lead to stronger and more meaningful outcomes for both the institution and community. Flinn describes this benefit in more detail, highlighting the evolving professional scope of archival institutions:

"One result ... might be that a build up of trust results eventually in direct, permanent responsibility for the archive passing into hands of the formal body, but in other cases the groups will wish to retain direct custody over their archive for the foreseeable future. In this view of professional duties, custody does not determine care and guidance for community collections, but rather such guidance is seen as a part of the community partnership and outreach priorities of the archive service."27

22. Doi, "Local Music Collections in Cultural Heritage Institutions: A Qualitative Systematic Review."

23. Christian Kelleher, "Archives Without Archives: (Re)Locating and (Re)Defining the Archive Through PostCustodial Praxis," Journal of Critical Library and Information Studies 1, no. 2 (July 7, 2017): 24, https://doi.org/10.24242/iclis.v1i2.29.

24. Doi, "Local Music Collections in Cultural Heritage Institutions: A Qualitative Systematic Review."

25. Society of American Archivists, "Postcustodial Theory of Archives," A Glossary of Archival and Records Terminology, accessed August 3, 2018, https://www2.archivists.org/glossary/terms/p/postcustodial-theory-ofarchives.

26. Andrew Flinn, "Community Histories, Community Archives: Some Opportunities and Challenges," Journal of the Society of Archivists 28, no. 2 (2007): 151-76, https://doi.org/10.1080/00379810701611936.

27. Flinn. 
This approach to relationship building serves to benefit both the institution and the community, and building partnerships based on respectful dialogue with local communities will ultimately serve to maintain long-lasting partnerships. Without this communication, we run the risk of alienating the community or building collections that do not accurately represent local narratives and histories.

\section{Limitations}

Although the survey was sent out to a number of institutions and librarians, we did not have access to a comprehensive list of local music collections or collection managers in Canadian libraries. Local music collections are advertised and promoted to varying degrees, which meant it was difficult to ensure that all potential participants in Canada were contacted. There is no way, therefore, to know the number of local music collection managers who did not receive the invitation to participate.

Responses collected are not representative of every province or territory in Canada and regional coverage is inconsistent. Notably, there were no responses in French or from Québec. It is difficult to know whether this is due to the timing of survey distribution, lack of interest, or because local music collecting is happening less in francophone institutions. This survey presents a snapshot in time, and new collections may have been created since it was distributed. New collection management strategies may be in practice by the time this article is published. Conversely, responses do not necessarily represent the work of past collection managers, even though some of the collections are historical in nature.

\section{Next Steps}

While this research is focused on local music collecting in libraries, other types of cultural heritage organizations are also engaged in developing local music collections and working to preserve and document local music histories in Canada. This study was aimed at capturing the professional practices and limitations of practice for librarians working with local music. Findings from this study build a picture of the professional practices currently in use in Canadian libraries. In particular, the open-ended responses also invite further thought on the significance and value of local music collections within the community, as well as their place in national and global music scenes. As part of the next phase of the Sounds of Home project, we will interview collectors across a broader range of organization types, including museums, archives, community organizations, and cultural centres. These interviews will focus less on professional practices and more on the role and consequence of local music collections and collectors within the community. The interviews will address the growing interest in local music topics across a wide range of disciplines, including music librarianship, and will seek to harness the mutual interest in these collections by both the news media and the public.

Responses to Part II of the survey (see Appendix I: Survey questions: English) asked participants to identify other collections in their communities and to share descriptions of their collections publicly. Data from these responses was stored and analyzed separately from the raw survey data in order to 
preserve the anonymity of the responses, but has since been used as a starting point for identifying potential interview participants. Information on collection locations and descriptions has been combined with previously collected data, which will serve as the basis for a publicly available directory of local music collections in Canada. We are also conducting exploratory work using geovisualization techniques to illuminate the relationship between music and place spatially.

There are parallels between the complexity of local music collecting practices and the discourse of music scenes scholarship. For example, the material evidence of local music scenes contained in local music collections is extensive; collections include a wide range of formats that are acquired by various means, representing various parts of a given local scene or scenes in a particular geographic location. Future researchers may wish to dig deeper into this idea of representation as it relates to music scenes, and theorize how local music collections can be imagined as containers of local music scenes.

The survey questions address professional considerations for managing local music collections in libraries and could be easily adapted to survey a different population, such as collectors in another country, geographic region, or a different disciplinary field, such as archives or museums.

\section{Conclusions}

The results of this survey highlight the diversity and complexity of professional practices with regard to local music collections in Canadian libraries. This practice is happening across the country and in a variety of library types. Local music collections themselves are shown to contain a wide range of materials and formats representative of local music communities at institutional, regional, and provincial levels. This diversity in content and description means that different local music collection managers are likely to define local music in different ways. While the local music collections represented in this survey are found in libraries, practices for managing them are derived both from archives and special collections librarianship. Working with local music necessitates strong ties with communities and must depend on strong community engagement and relationship building.

These findings are significant in that they, for the first time, present an aggregated view of this area of local music collection management and music librarianship and a more comprehensive understanding of the nature and extent of local music collections in Canadian libraries. This study will allow us, and others, to further explore ideas about the connection and shifting boundaries among local, national, and global cultures as evidenced in music. 


\section{Acknowledgements}

This research was supported by the Social Sciences and Humanities Research Council of Canada. The survey protocol was tested during the 2018 Annual Meeting of the Music Library Association. Thanks to A. Leach, K. Hujda, S. Lewin-Lane, C. Dow, M. Gilmore, J. Vallier, and S. Outhier who provided valuable time and feedback on the survey design. Thanks to C. Polischuk (University of Saskatchewan) and J. Doiron (University of Alberta) for advice on data cleaning, analysis, and sharing.

\section{Bibliography}

Allen, Lara. "Preserving a Nation's Heritage: The Gallo Music Archive and South African Popular Music." Fontes Artis Musicae, no. 3 (2007): 263.

American Library Association. "Guidelines: Competencies for Special Collections Professionals," July 8, 2008. http://www.ala.org/acrl/standards/comp4specollect.

Baker, Sarah, ed. Preserving Popular Music Heritage: Do-It-Yourself, Do-It-Together. Routledge Research in Music 11. New York: Routledge, 2015.

Baker, Sarah, and Jez Collins. "Sustaining Popular Music's Material Culture in Community Archives and Museums." International Journal of Heritage Studies 21, no. 10 (November 26, 2015): 983-96. https://doi.org/10.1080/13527258.2015.1041414.

Baker, Sarah, Peter Doyle, and Shane Homan. "Historical Records, National Constructions: The Contemporary Popular Music Archive." In Popular Music and Society, 39:8-27. Abingdon, Oxfordshire, United Kingdom: Routledge, 2016.

Belford, Richard. "Building a Regional Music Collection: The Saskatchewan Experience." CAML Review / Revue de l'ACBM 35, no. 1 (2007): 19-22.

Bennett, Andy. "Consolidating the Music Scenes Perspective." Poetics: Journal of Empirical Research on Culture, the Media and the Arts 32, no. 3-4 (2004): 223-34.

- - . "Popular Music and the 'Problem' of Heritage." In Sites of Popular Music Heritage: Memories, Histories, Places, 15-27. Routledge Studies in Popular Music 4. New York: Routledge, 2015.

Berger, Sidney E. "What Is so Rare...: Issues in Rare Book Librarianship." Library Trends 36, no. 1 (1987). http://hdl.handle.net/2142/7513.

Bhattacherjee, Anol. Social Science Research: Principles, Methods, and Practices. Textbooks Collection 3. Global Text Project, 2012. https://scholarcommons.usf.edu/oa_textbooks/3/.

Biddle, Ian D., and Vanessa Knights. Music, National Identity and the Politics of Location : Between the Global and the Local. Ashgate Popular and Folk Music Series. Burlington, VT: Ashgate, 2007. 
Connell, John, and Chris Gibson. Sound Tracks : Popular Music, Identity, and Place. Critical Geographies 17. London: Routledge, 2003.

Dewe, Michael. "Local Studies and Libraries." In Local Studies Collection Management. London: Routledge, 2016.

Dixon, Diana. "From Manuscripts to Metadata: The Changing Face of Local Studies Librarianship." APLIS 24, no. 2 (June 2011): 74-81.

Doi, Carolyn. "Local Music Collections in Cultural Heritage Institutions: A Qualitative Systematic Review." Fontes Artis Musicae 65, no. 4 (2018).

- - . "Local Music Collections: Strategies for Digital Access, Presentation, and Preservation-A Case Study." New Review of Academic Librarianship 21, no. 2 (2015): 256-63. https://doi.org/10.1080/13614533.2015.1022663.

Doi, Carolyn, and Sean Luyk. "Local Music Collections and Collecting in Canada," September 18, 2018. https://doi.org/10.7939/DVN/WAJ9UG.

Epstein, Dena. Sinful Tunes and Spirituals: Black Folk Music to the Civil War. Urbana: University of Illinois Press, 2003.

Epstein, Dena J. "On Collecting Materials for Local Music Histories." Notes: Quarterly Journal of the Music Library Association 24, no. 1 (1967): 18-21. https://doi.org/10.2307/894777.

Fairley, Jan. "The 'local' and 'Global' in Popular Music," 272-89. Cambridge Companions to Music. New York, NY: Cambridge University Press, 2001.

Flinn, Andrew. "Community Histories, Community Archives: Some Opportunities and Challenges." Journal of the Society of Archivists 28, no. 2 (2007): 151-76. https://doi.org/10.1080/00379810701611936.

Gramit, David. "The Transnational History of Settler Colonialism and the Music of the Urban West: Resituating a Local Music History." American Music 32, no. 3 (2014): 272-91. https://doi.org/10.5406/americanmusic.32.3.0272.

Guilbault, Jocelyne. "On Redefining the Local through World Music." In Ethnomusicology: A Contemporary Reader, 137-46. New York: Routledge, 2006.

Hathaway, Edward W. "Developing a State Archive of Local Music Materials." Notes: Quarterly Journal of the Music Library Association 45, no. 3 (1989): 483-94.

Kelleher, Christian. "Archives Without Archives: (Re)Locating and (Re)Defining the Archive Through Post-Custodial Praxis." Journal of Critical Library and Information Studies 1, no. 2 (July 7, 2017). https://doi.org/10.24242/jclis.v1i2.29.

Kmiech, Veronica. "In Other News: The Significance of Canadian Media Sources in an Analysis of Local Music Collection Literature." CAML Review / Revue de l'ACBM 46, no. 1 (2018): 6-16. 
Kruse, Holly. Site and Sound: Understanding Independent Music Scenes. Music/Meanings, vol. 1. New York, NY: P. Lang, 2003.

Leonard, Marion. "Constructing Histories through Material Culture: Popular Music, Museums and Collecting." Popular Music History 2, no. 2 (2007): 147-67. https://doi.org/10.1558/pomh.v2i2.147.

Luyk, Sean. "Scene but Not Heard: Collecting Local Music." CAML Review / Revue de l'ACBM 41, no. 1 (2013): 22-33.

Peterson, Richard A., and Andy Bennett. Music Scenes: Local, Translocal \& Virtual. Nashville, TN: Vanderbilt University Press, 2004.

Rafferty, Michael. "Compiling a Comprehensive Local Music Archive - Some Problems." Local Studies Librarian 20, no. 2 (2001): 12-13.

Society of American Archivists. "Postcustodial Theory of Archives." A Glossary of Archival and Records Terminology. Accessed August 3, 2018. https://www2.archivists.org/glossary/terms/p/postcustodial-theory-of-archives.

Spivacke, Harold. "Collection of Musical Material of Local Interest." Music Library Association Notes, no. 8 (August 3, 1940): 49-54.

Stevenson, Robert Murrell. "Local Music History Research in Los Angeles Area Libraries." InterAmerican Music Review 10, no. 1 (1988): 19-38.

Straw, Will. "Systems of Articulation, Logics of Change: Communities and Scenes in Popular Music." Cultural Studies 5, no. 3 (1991): 368-88.

Vallier, John. "Sound Archiving Close to Home: Why Community Partnerships Matter." Notes: Quarterly Journal of the Music Library Association 67, no. 1 (2010): 39-49.

Wanser, Jeff. "Collecting and Collaborating to Build Community: The Evolution of a Local Music Collection at a Small Liberal Arts College Library." Technical Services Quarterly 31, no. 4 (October 2, 2014): 332-57. https://doi.org/10.1080/07317131.2014.908586.

Winling, Priscilla. "Bringing the Local Music Scene to the Public Libraries Network of Strasbourg: A Live Collection." Fontes Artis Musicae 59, no. 2 (2012): 127-33. http://www.jstor.org/stable/42765570. 


\title{
Appendix 1: Survey Questionnaire, English
}

\author{
Consent \\ You are invited to participate in a research study entitled: Sounds of Home: Exploring Local Music Collections and \\ Collecting in Canada \\ Researcher(s): \\ - Carolyn Doi (Principal Investigator), Assistant Librarian (Music), University Library, University of \\ Saskatchewan, 306966 2433, carolyn.doi@usask.ca \\ - Sean Luyk (Co-Investigator), Digital Initiatives Projects Librarian, University of Alberta Libraries, \\ sean.luyk@ualberta.ca, 780-492-6779
}

\section{Purpose(s) and Objective(s) of the Research:}

This project will seek to understand the state of local music collections across Canada. Specifically, we aim to: identify where collections of local music are held, what music(s) they document, and what evidentiary value they possess; understand the perceived value of collecting local music, and record local music collection management practices currently used by public institutions to determine areas where practices may be improved.

\section{Procedures:}

This research uses a questionnaire, which can be completed online. It is estimated the survey will take no more than 20 minutes to complete. Please feel free to ask any questions regarding the procedures and goals of the study or your role.

\section{Funded by:}

The University of Saskatchewan President's SSHRC Research Fund

The Social Sciences \& Humanities Research Council (SSHRC) Insight Development Grant

\section{Potential Risks:}

There are no known or anticipated risks to you by participating in this research.

\section{Potential Benefits:}

These findings will:

1) benefit music librarians, music libraries, and libraries collecting local music materials by providing strategies for managing local music collections and a comprehensive summary of how local music materials are identified, collected, preserved, and made accessible.

2) be used to identify the location of local music collections in Canada with the goal of providing locational data and collection descriptions in a digital mapping environment.

Please note: Some participants may not see an immediate/direct benefit to participating.

\section{Confidentiality:}

IP addresses and emails are collected but will be removed prior to analysis. The data from part one of the survey (collection scope and collecting practices) will be published and presented, but the data will be reported in aggregate form, so that it will not be possible to identify individual participants. There may be limits to the confidentiality due to context and individual participants may be identifiable because of the size of the sample. The data collected in section two of this survey (Next Steps) will be used to identify the location of local music collections in Canada, and to identify participants for follow up interviews and site visits. Data collected in this section of the survey will not be anonymous. Participants may choose to answer one or both sections of the survey. This survey is hosted by Voxco, a Canadian-owned and managed company whose data is securely stored in Canada. Consider printing this page for your records. 


\section{Storage of Data:}

The data will be stored on password protected computer files at the Social Sciences Research Lab, University of Saskatchewan. The data will be destroyed by electronic file deletion after 5 years of storage. The data from Part One (collection scope and collecting practices) of this study will be archived through the University of Alberta Dataverse, a service that helps researchers publish, analyze, distribute and preserve their data and datasets (https://dataverse.library.ualberta.ca/dvn/). The data will be available to the public and may be used by other researchers in the future.

Right to Withdraw: Your participation is voluntary and you can answer only those questions that you are comfortable with. You may withdraw from the research project for any reason, at any time without explanation or penalty of any sort. Should you wish to withdraw please contact either of the researchers to have your data removed from the study results. Your right to withdraw data from the study will apply until results have been disseminated after June 2018. After this date, it is possible that some form of research dissemination will have already occurred and it may not be possible to withdraw your data.

\section{Follow up:}

Results from this study will be presented at the 2018 Annual Meeting of the Canadian Association of Music Libraries in Regina, SK. Presentation notes will be posted online following the presentation. Survey participants will be notified by email with a link to the presentation notes when they are available.

\section{Questions or Concerns:}

Contact the researchers using the information at the top of page 1; This research project has been approved on ethical grounds by the University of Saskatchewan and University of Alberta Research Ethics Boards. Any questions regarding your rights as a participant may be addressed to those committees through the Research Ethics Offices at ethics.office@usask.ca (306) 966-2975 (out of town participants may call toll free (888) 966-2975) and/or The plan for this study has been reviewed by a Research Ethics Board at the University of Alberta. If you have questions about your rights or how research should be conducted, you can call (780) 492-2615. This office is independent of the researchers.

\section{Consent}

By completing and submitting the questionnaire, YOUR FREE AND INFORMED CONSENT IS IMPLIED and indicates that you understand the above conditions of participation in this study.

\section{Part 1}

\section{Sounds of Home: Exploring Local Music Collections and Collecting in Canada}

\section{Q1 Does your library manage one or more collections of local or regional music?*}

*For the purposes of this research, local music collections are defined as library collections where the scope includes a delimited geographic area (e.g. town, city, neighborhood, province, territory, region, etc).

- Yes

- No

\section{Q2 Where is your library located?}

- Alberta

- British Columbia

- Manitoba

- New Brunswick

- Newfoundland and Labrador

- Nova Scotia

- Ontario

- $\quad$ Prince Edward Island 
- Quebec

- Saskatchewan

- Northwest Territories

- Nunavut

- Yukon

- $\quad$ Other (please specify)

Q3 What type of library do you work in?

- Academic library

- Public library

- Special library

- $\quad$ Other (please explain)

\section{Collection Scope}

Q4 What is the scope of your local music collection(s)?

Q5 What formats are included in your local music collection(s)?

- Sound recordings [45 rpm, 78 rpm, 33 1/3 rpm, CD, reel to reel tape, cassette tape, 8-track tape, born digital, albums, etc.]

- Video recordings

- $\quad$ Notated music [piano roll, score, sheet music, etc.]

- Music manuscripts

- Monographs

- Instructional materials

- $\quad$ Printed ephemera

- $\quad$ Objects [e.g. coasters, buttons, patches, etc.]

- Concert Programs

- Posters

- Photographs

- Other (please specify)

Q6 How are users currently able to access your local music collection(s)? (check all that apply)

- Online

- In person

- Collection is not accessible

- $\quad$ Other (please specify)

Q7 Have items in your local music collection(s) been catalogued?

- Yes

- No

- Partially

Q7a You answered that items in your local music collection(s) are fully or partially catalogued. Is metadata used to indicate that catalogued items are part of a local music collection?

- Yes

- No

- Sometimes

Q7b How is metadata used to indicate that items are part of a local music collection?

- Added name field 
- $\quad$ Added series note

- $\quad$ Added subject headings

Q8 Who are the users of your local music collection(s)? (rank from most frequent to least frequent users. Only select as many as apply) To rank the primary users, drag them into the box on the right (with the most frequent users at the top).

\begin{tabular}{|l|}
\hline Researchers \\
\hline Students \\
\hline Members of the community \\
\hline Visitors from other communities \\
\hline Donors \\
\hline Don't know \\
\hline Other (please specify) \\
\hline
\end{tabular}

Q8a You selected "other", please specify:

Q9 How do your users make use of your local music collection(s)? (select all that apply)

- Scholarly research

- Historical research

- Family research

- Community research

- Teaching

- Don't know

- $\quad$ Other (please specify)

\section{Promotion}

Q10 How are the local music collection(s) promoted? (check all that apply)

- Development of specific branding for the collection(s) (i.e. logo development)

- Community engagement

- $\quad$ Events (e.g. presentations, tables at industry events, conferences, etc.)

- Development of promotional film(s)

- Development of print promotional materials (i.e. posters, pamphlets, brochures, etc.)

- Publications in newspaper/media sources (online or print)

- Online advertising or social media activity (i.e. social media presence, blog, website, etc.)

- Radio or podcasts

- Scholarly article describing the collection(s)

- $\quad$ Other (please specify)

- Not applicable

\section{Collection Development}

Q11 Are new items being added to the local music collection(s)?

- Yes

- No 
Q12 How often do you acquire local music materials from the following sources?

\begin{tabular}{|l|l|l|l|l|l|}
\hline & Never & Rarely & Sometimes & Frequently & Very frequently \\
\hline Individual artists or bands & & & & & \\
\hline $\begin{array}{l}\text { Community based organizations or groups } \\
\text { (e.g. music society, arts organization, } \\
\text { community centre, etc.) }\end{array}$ & & & & & \\
\hline $\begin{array}{l}\text { Music stores or vendors (e.g. online or } \\
\text { physical) }\end{array}$ & & & & & \\
\hline At events & & & & & \\
\hline Donations & & & & & \\
\hline Music label or publisher & & & & & \\
\hline $\begin{array}{l}\text { Creating recordings of oral histories or live } \\
\text { performances }\end{array}$ & & & & & \\
\hline Social media & & & & & \\
\hline Other (please specify) & & & & & \\
\hline
\end{tabular}

Q13 How useful have the following tools or strategies been when identifying and selecting local music for acquisition?

\begin{tabular}{|l|l|l|l|l|l|l|}
\hline & n/a & $\begin{array}{c}\text { Not at } \\
\text { all } \\
\text { useful }\end{array}$ & $\begin{array}{c}\text { Minimally } \\
\text { useful }\end{array}$ & $\begin{array}{c}\text { Somewhat } \\
\text { useful }\end{array}$ & $\begin{array}{c}\text { Useful } \\
\text { useful }\end{array}$ \\
\hline $\begin{array}{l}\text { Establishing or updating a collection } \\
\text { development policy }\end{array}$ & & & & & & \\
\hline $\begin{array}{l}\text { Gathering suggestions through community } \\
\text { engagement activities }\end{array}$ & & & & & & \\
\hline $\begin{array}{l}\text { Gathering suggestions by building or maintaining } \\
\text { community partnerships }\end{array}$ & & & & & & \\
\hline $\begin{array}{l}\text { Keeping or building lists (e.g. spreadsheet, } \\
\text { amazon wish list, etc.) }\end{array}$ & & & & & & \\
\hline $\begin{array}{l}\text { Asking for suggestions from the public through } \\
\text { the media (e.g. newspaper article asking for } \\
\text { donations) }\end{array}$ & & & & & & \\
\hline Conducting research on local music & & & & & & \\
\hline $\begin{array}{l}\text { Selecting from offerings at music stores or from } \\
\text { music vendors }\end{array}$ & & & & & & \\
\hline Getting suggestions (e.g. staff, students, clients) & & & & & & \\
\hline Other (please specify) & & & & & \\
\hline
\end{tabular}

Q14 How are funds to purchase new local music materials secured? (check all that apply)

- Donations from members of the community

- Government funding

- Grants

- From the institution

- A community-based association or organization

- Designated endowment funds

- Other (please specify) 
Q15 What strategies are important when acquiring local music materials? (rank in order of importance from most important to least important. Select only those that apply) To rank the strategies, drag them into the box on the right (most important at the top).

\begin{tabular}{|l|}
\hline Establishing donor agreements \\
\hline Establishing licensing agreements \\
\hline Maintaining flexibility \\
\hline Hosting events to identify or collect local music \\
\hline Promotional activities \\
\hline Advocacy \\
\hline Other (please specify below) \\
\hline
\end{tabular}

Q15a You selected "other", please specify:

Preservation

Q16 Where is the physical location of the local music collection(s) within your institution? (check all that apply)

- Archives or special collections

- Interfiled with other music collections

- Onsite storage

- Offsite storage

- Special collection within a music library

- Other (please specify)

Q17 What steps have been taken to preserve some or all of the collection(s)? (check all that apply)

- Physical preservation

- Digital preservation

- Not applicable

Q18 What steps have been taken to physically preserve the materials in the local music collection(s)?

Q19 What steps have been taken to digitally preserve the materials in the local music collection(s)?

Q20 Is there anything else you would like to add about local music collections or collecting? 


\section{Appendix 2: Survey Questionnaire, French}

Formulaire de consentement du participant

\section{CONSENTEMENT}

*Dans ce questionnaire, le masculin est utilisé sans discrimination, dans le seul but d'alléger le texte.

Nous vous invitons à participer au projet de recherche Sounds of Home: Exploring Local Music Collections and Collecting in Canada (Sons familiers : étudier les collections et la collecte de musique locale au Canada)

\section{Chercheurs:}

- Carolyn Doi (chercheure principale), bibliothécaire adjointe (musique), Bibliothèque de l'Université, Université de la Saskatchewan, carloyn.doi@usask.ca, 306-966-2433.

- Sean Luyk (cochercheur), bibliothécaire responsable des projets numériques, Bibliothèques de l'Université de l'Alberta, Université de l'Alberta, sean.luyk@ualberta.ca, 780-492-6779.

\section{Objectifs du projet de recherche:}

Nous avons pour objectif de dresser un bilan des collections de musique locale partout au Canada et souhaitons plus précisément :

- déterminer à quels endroits se trouvent les collections de musique, ainsi que leur contenu et leur valeur de témoignage;

- comprendre la valeur accordée à la collecte de musique locale;

- consigner les pratiques que les établissements utilisent pour gérer les collections de musique locale et proposer des améliorations, s'il y a lieu.

\section{Procédure:}

Les sondés doivent répondre à un questionnaire qu'ils peuvent remplir en ligne. On estime que 20 minutes suffisent pour le terminer. Pour toute question relative à la procédure et aux objectifs de ce projet de recherche, ou du rôle que vous y jouez, veuillez communiquer avec nous.

\section{Financement:}

- Une subvention d'exploration du Conseil de recherches en sciences humaines (CRSH)

- Une subvention de développement Savoir du CRSH

\section{Risques possibles:}

La participation à ce projet de recherche ne comporte aucun risque connu ou anticipé.

\section{Bénéfices possibles:}

Les résultats du sondage :

- $\quad$ profiteront aux bibliothécaires et aux bibliothèques de musique, ainsi qu'aux bibliothèques qui collectent de la musique locale, car nous leur fournirons des stratégies pour gérer leurs collections de musique locale, ainsi qu'un condensé portant sur l'identification, la collecte et la conservation de ces collections, de même que leur accessibilité.

- $\quad$ seront utilisés pour dresser une description des collections de musique locale au Canada et pour découvrir les lieux où elles sont abritées. Ces renseignements seront intégrés dans une cartographie numérique.

Remarque : certains sondés pourraient ne pas observer de bénéfice immédiat relatif à leur participation.

\section{Confidentialité :}

- Nous recueillerons les adresses IP et courriel des participants, mais elles seront supprimées avant l'analyse.

- Nous publierons et présenterons les données de la première partie du sondage (ayant pour objet l'ampleur des collections et les pratiques en matière de collecte), mais nous en regrouperons les données, de sorte qu'il sera impossible d'identifier les sondés. 
- II se peut toutefois qu'en raison du contexte et de la taille de l'échantillon, on puisse identifier certains participants.

- Nous nous servirons des données récoltées dans la deuxième partie du sondage (Étapes suivantes) pour déterminer où se trouvent les collections de musique locale au Canada, ainsi que pour identifier les participants au projet de recherche, dans le but de les interviewer et de visiter leur bibliothèque. Les données compilées dans cette partie du sondage ne seront donc pas anonymes. Les participants peuvent choisir de remplir une seule partie du sondage, ou les deux.

- Ce sondage est hébergé sur Voxco, une firme détenue et gérée par des Canadiens, dont les données sont archivées de façon sécuritaire au Canada.

- Veuillez imprimer la présente page pour vos dossiers.

\section{Stockage des données:}

- Vos données seront stockées sur des fichiers électroniques protégés par mot de passe dans les Social Sciences Research Laboratories (Laboratoires de recherche en sciences sociales) de l'Université de la Saskatchewan. Elles seront supprimées électroniquement au bout de cinq ans.

- Les données de la première partie du sondage (ayant pour objet l'ampleur des collections et les pratiques en matière de collecte) seront archivées sur le réseau Dataverse de l'Université de l'Alberta. Les chercheurs utilisent ce réseau pour publier, analyser, conserver et disséminer leurs données et ensembles de données (https://dataverse.library.ualberta.ca/dvn/). Les données seront ultérieurement mises à la disposition du public et des chercheurs.

\section{Droit de retirer son consentement :}

Vous prenez part de plein gré à ce projet de recherche et pouvez choisir de ne répondre qu'à certaines questions. En outre, vous pouvez mettre fin à votre participation en tout temps et pour n'importe quelle raison sans vous expliquer ou subir de sanction. Pour retirer votre consentement et faire supprimer vos données du sondage, veuillez communiquer avec l'un des deux chercheurs. Vous aurez jusqu'au mois de juin 2018 pour ce faire. II est possible qu'après cette date, nous ayons déjà disséminé une partie de vos données et que nous ne puissions les supprimer.

\section{Suivi :}

Nous présenterons les résultats de ce sondage lors de l'assemblée générale annuelle de 2018 de l'Association canadienne des bibliothèques, archives et centres de documentation musicaux, qui se tiendra à Regina, en Saskatchewan. Les notes des présentateurs seront affichées en ligne à la fin de leur séance. Les participants recevront un courriel les avisant de la disponibilité des notes et leur fournissant un lien pour y accéder.

\section{Questions et commentaires:}

- Pour toute question ou tout commentaire, veuillez communiquer avec l'un des deux chercheurs dont les coordonnées se trouvent à la page 1.

- Le Bureau d'éthique de la recherche de l'Université de la Saskatchewan a approuvé la dimension éthique de ce projet de recherche. Les sondés peuvent faire parvenir toute question relative à leurs droits à l'adresse : ethics.office@usask.ca ou téléphoner au : 306-966-2975. Les participants de l'extérieur peuvent téléphoner sans frais au : 888-966-2975.

- Le Bureau d'éthique de la recherche de I'Université de l'Alberta a révisé le plan de ce projet de recherche. Pour toute question concernant vos droits ou la procédure de ce projet, veuillez téléphoner au : 780-492-2615. Les chercheurs ne sont pas associés à ce bureau.

\section{Consentement :}

En remplissant et en envoyant ce sondage, VOUS INDIQUEZ VOTRE CONSENTEMENT LIBRE ET ÉCLAIRÉ, et affirmez comprendre les conditions de participation à ce projet. 
Partie 1

Sons familiers : étudier les collections et la collecte de musique locale au Canada

Q1 Votre bibliothèque contient-elle une ou plusieurs collections de musique locale ou régionale*?

*Aux fins de ce projet de recherche, on définit les collections de musique locale comme provenant d'une région géographique particulière (p. ex. ville, village, quartier, province, territoire, etc.)

- Oui

- Non

\section{Démographie}

Q2 Dans quelle province se situe votre bibliothèque?

- Alberta

- Colombie-Britannique

- Île-du-Prince-Édouard

- Manitoba

- Nouveau-Brunswick

- Nouvelle-Écosse

- Nunavut

- Ontario

- Québec

- Saskatchewan

- Terre-Neuve et Labrador

- Territoires du Nord-Ouest

- Yukon

- Autre (préciser)

Q3 Dans quel genre de bibliothèque travaillez-vous?

- Bibliothèque d'un établissement d'enseignement supérieur

- Bibliothèque publique

- Bibliothèque spécialisée

- Autre (expliquer)

\section{Ampleur des collections}

Q4 Quelle est l'ampleur de votre (vos) collection(s) de musique locale?

Q5 Quels formats retrouve-t-on dans votre (vos) collection(s) de musique locale?

- Enregistrements sonores (45 tours, 78 tours, 33 1/3 tours, CD, bobines, cassettes, rubans à huit pistes, albums numériques, etc.)

- Enregistrements vidéo

- Musique transcrite (partitions numériques en bandes, partitions, musique en feuilles, etc.)

- Manuscrits de musique

- Monographies

- Matériel didactique

- Imprimés éphémères

- Objets (p. ex. sous-verres, macarons, badges)

- Programmes de concert

- Affiches

- Photographies

- Autres (préciser) 
Q6 À l'heure actuelle, comment vos usagers ont-ils accès à votre (vos) collection(s) de musique? (veuillez cocher toutes les cases qui s'appliquent)

- En ligne

- En personne

- Notre (nos) collection(s) n'est (ne sont) pas accessible(s)

- Autre (préciser)

Q7 Les objets de votre (vos) collection(s) de musique locale ont-ils été catalogués?

- Oui

- Non

- En partie

Q7a Si vous avez répondu à la question 7 que votre (vos) collection(s) de musique est (sont) cataloguée(s), en partie ou en entier, se sert-on de métadonnées pour indiquer que les objets catalogués font partie d'une collection de musique locale?

- Oui

- Non

- Parfois

Q7b Comment se sert-on de métadonnées pour indiquer que des objets font partie d'une collection de musique locale?

- Nom de champ ajouté

- Note de collection ajoutée

- Vedette-matière ajoutée

- Autre (préciser)

Q8 Qui sont les usagers de votre (vos) collection(s) de musique locale? (Veuillez commencer par les usagers les plus fréquents en faisant glisser cette catégorie dans la case de droite. Ne choisissez que les réponses qui s'appliquent.)

- Chercheurs

- Étudiants

- Membres de la collectivité

- Visiteurs

- Mécènes

- Je l'ignore

- Autre (préciser)

Q8a Si vous avez coché « autre », veuillez préciser :

Q9 Dans quel but vos usagers se servent-ils de votre (vos) collection(s) de musique? (veuillez cocher toutes les cases qui s'appliquent)

- Recherche savante

- Recherche historique

- Recherche familiale

- Recherche communautaire

- Enseignement

- Je l'ignore

- $\quad$ Autre (préciser) 


\section{Promotion}

Q10 Comment fait-on la promotion de votre (vos) collection(s) de musique locale? (veuillez cocher toutes les cases qui s'appliquent)

- Création d'une image de marque pour la (les) collection(s) (p. ex. logo)

- Engagement de la collectivité

- Événements (p. ex. présentations, tables lors de congrès, conférences, etc.)

- Création de films publicitaires

- $\quad$ Création de matériel de promotion (p. ex. affiches, dépliants, brochures, etc.)

- Publications dans les journaux et les médias (imprimés et en ligne)

- Annonces en ligne ou sur les médias sociaux (p. ex. présence sur les médias sociaux, blogues, sites Web, etc.)

- Radio ou balado

- Article savant décrivant la (les) collection(s)

- Autre (préciser)

- Sans objet

\section{Pratiques en matière de collecte}

\section{Q11 Ajoute-t-on de nouveaux objets à votre (vos) collection(s) de musique?}

- Oui

- Non

\section{Q12 À quelle fréquence faites-vous l'acquisition de musique locale des sources suivantes?}

\begin{tabular}{|l|l|l|l|l|l|}
\hline & Jamais & Rarement & Parfois & Fréquemment & Couramment \\
\hline Artistes ou groupes & & & & & \\
\hline $\begin{array}{l}\text { Organismes communautaires } \\
\text { (p. ex. sociétés de musique, } \\
\text { organisations artistiques, centres } \\
\text { communautaires, etc.) }\end{array}$ & & & & & \\
\hline $\begin{array}{l}\text { Magasins ou marchands de musique } \\
\text { (traditionnels ou en ligne) }\end{array}$ & & & & & \\
\hline Lors d'événements & & & & & \\
\hline Dons & & & & & \\
\hline $\begin{array}{l}\text { Éditeurs de musique ou maisons de } \\
\text { disques }\end{array}$ & & & & & \\
\hline $\begin{array}{l}\text { Enregistrements de récits ou de } \\
\text { concerts }\end{array}$ & & & & & \\
\hline Médias sociaux & & & & & \\
\hline Autre (préciser) & & & & & \\
\hline
\end{tabular}

Q13 Les outils suivants vous ont-ils été utiles pour identifier et choisir des collections de musique locale dans le but de les acquérir?

\begin{tabular}{|c|c|c|c|c|c|c|}
\hline & $\begin{array}{l}\text { Sans } \\
\text { objet }\end{array}$ & $\begin{array}{l}\text { Pas du } \\
\text { tout utile }\end{array}$ & $\begin{array}{l}\text { À peine } \\
\text { utile }\end{array}$ & $\begin{array}{l}\text { Un peu } \\
\text { utile }\end{array}$ & Utile & $\begin{array}{l}\text { Très } \\
\text { utile }\end{array}$ \\
\hline $\begin{array}{l}\text { Établir ou mettre à jour une politique } \\
\text { développement des collections }\end{array}$ & & & & & & \\
\hline $\begin{array}{l}\text { Recueillir des suggestions au moyen } \\
\text { d'activités communautaires }\end{array}$ & & & & & & \\
\hline
\end{tabular}




\begin{tabular}{|l|l|l|l|l|l|l|}
\hline $\begin{array}{l}\text { Recueillir des suggestions en créant ou en } \\
\text { entretenant des partenariats } \\
\text { communautaires }\end{array}$ & & & & & & \\
\hline $\begin{array}{l}\text { Se créer ou sauvegarder des listes (p. ex. } \\
\text { tableurs, liste de souhaits sur amazon, etc.) }\end{array}$ & & & & & & \\
\hline $\begin{array}{l}\text { Demander au moyen des médias des } \\
\text { suggestions du public (p. ex. article de } \\
\text { journal sollicitant des dons) }\end{array}$ & & & & & & \\
\hline $\begin{array}{l}\text { Effectuer une recherche sur la musique } \\
\text { locale }\end{array}$ & & & & & & \\
\hline $\begin{array}{l}\text { Parcourir la sélection offerte par des } \\
\text { magasins ou des marchands de musique }\end{array}$ & & & & & & \\
\hline $\begin{array}{l}\text { Recueillir des suggestions (p. ex. personnel, } \\
\text { étudiants, clients) }\end{array}$ & & & & & & \\
\hline Autre (préciser) & & & & & & \\
\hline
\end{tabular}

Q14 Comment vous procurez-vous les fonds nécessaires à l'acquisition de nouvelles collections de musique locale (veuillez cocher toutes les cases qui s'appliquent)

- Dons des membres de la collectivité

- Financement public

- Subventions

- Établissement d'enseignement

- Organisme ou association communautaire

- Fonds de dotation nommé

- Autre (préciser)

Q15 Quelles stratégies comptent le plus pour vous quand il s'agit d'acquérir des objets relatifs à une collection de musique locale? (Veuillez classer en ordre décroissant d'importance en faisant glisser les stratégies dans la case de droite. Ne choisir que les réponses qui s'appliquent.)

- Établir des ententes avec des mécènes

- Établir des licences d'utilisation

- Demeurer flexible

- Organiser des activités dans le but de découvrir de la musique locale et d'enrichir les collections

- Faire la promotion d'activités

- Constituer un groupe de pression

- $\quad$ Autre (préciser ci-dessous)

Q15a Vous avez coché « autre »; veuillez préciser :

\section{Conservation}

Q16 À quel endroit garde-t-on votre (vos) collection(s) de musique au sein de votre établissement? (veuillez cocher toutes les cases qui s'appliquent)

- Archives ou collections spéciales

- Interclassée(s) parmi les autres collections de musique

- Entreposée(s) sur place

- Entreposée(s) ailleurs

- Collection(s) spéciale(s) dans une bibliothèque de musique

- Autre (préciser) 
Q17 Quelles démarches avez-vous entreprises pour conserver toutes les collections ou certaines d'entre elles? (veuillez cocher toutes les cases qui s'appliquent)

- Conservation physique

- Conservation numérique

- Sans objet

Q18 Quelles démarches avez-vous entreprises pour conserver, sur support physique, tous les objets faisant partie de votre (vos) collection(s) de musique?

Q19 Quelles démarches avez-vous entreprises pour conserver, sur support numérique, tous les objets faisant partie de votre (vos) collection(s) de musique?

Q20 Souhaitez-vous ajouter un commentaire relatif aux collections ou à la collecte de musique local 